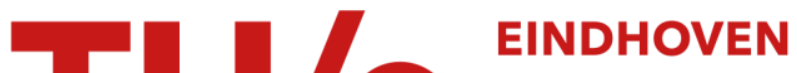 UNIVERSITY OF TECHNOLOGY
}

\section{Growth and remodeling of arterial tissue}

\section{Citation for published version (APA):}

Machyshyn, I., Bovendeerd, P. H. M., Ven, van de, A. A. F., Rongen, P. M. J., \& Vosse, van de, F. N. (2007). Growth and remodeling of arterial tissue. Poster session presented at Mate Poster Award 2007 : 12th Annual Poster Contest.

\section{Document status and date:}

Published: 01/01/2007

\section{Document Version:}

Publisher's PDF, also known as Version of Record (includes final page, issue and volume numbers)

\section{Please check the document version of this publication:}

- A submitted manuscript is the version of the article upon submission and before peer-review. There can be important differences between the submitted version and the official published version of record. People interested in the research are advised to contact the author for the final version of the publication, or visit the DOI to the publisher's website.

- The final author version and the galley proof are versions of the publication after peer review.

- The final published version features the final layout of the paper including the volume, issue and page numbers.

Link to publication

\section{General rights}

Copyright and moral rights for the publications made accessible in the public portal are retained by the authors and/or other copyright owners and it is a condition of accessing publications that users recognise and abide by the legal requirements associated with these rights.

- Users may download and print one copy of any publication from the public portal for the purpose of private study or research.

- You may not further distribute the material or use it for any profit-making activity or commercial gain

- You may freely distribute the URL identifying the publication in the public portal.

If the publication is distributed under the terms of Article $25 f a$ of the Dutch Copyright Act, indicated by the "Taverne" license above, please follow below link for the End User Agreement:

www.tue.nl/taverne

Take down policy

If you believe that this document breaches copyright please contact us at:

openaccess@tue.nl

providing details and we will investigate your claim. 


\author{
I. Machyshyn ${ }^{1}$, P. Bovendeerd ${ }^{1}$, A. van de Ven ${ }^{2}$, P. Rongen ${ }^{3}$, F. van de Vosse ${ }^{1}$ \\ ${ }^{\mathrm{I}}$ Biomechanics \& Tissue Engineering (BMTE), Cardiovascular Biomechanics \\ ${ }^{2}$ Mathematics and Computer Science, TU/e \\ 3 X-ray Pre-development, Philips Medical Systems, Best
}

\section{Introduction}

Living tissues continuously undergo growth, i.e. reorganization or renovation, and remodeling, i.e. a change in mass. Modeling both growth and remodeling (G\&R) of the vascular tissue is aimed to provide the insight into the adaptation of the tissue, in the healthy and diseased state, and upon surgical intervention.

\section{Material and methods}

We model the tissue as two component constrained mixture, composed of anisotropic collagen fibres, and an isotropic matrix. The remodeling of the tissue is attributed to the degradation and the deposition of collagen. To keep track of properties of collagen fibres deposited at different times, we consider a collagen generation, a bundle of collagen fibres, deposited at time interval $(t, t+\Delta t)$.

Collagen degradation. Generations degrade with time, gradually decreasing their mass, until complete disappearance. Collagen deposition. To compensate for the loss of collagen, a new collagen generation is created (Fig. 1).
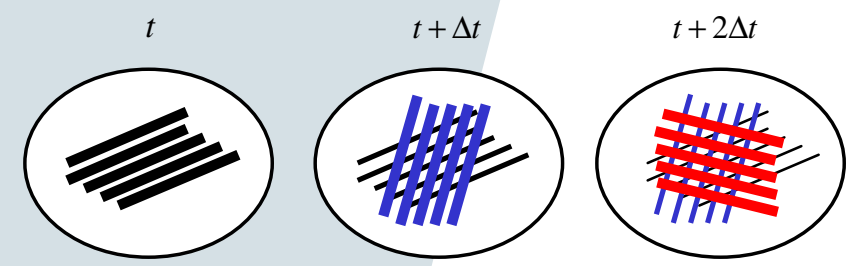

Fig.1 Scheme of collagen degradation and deposition. At $t=t_{n}$ a collagen generation, represented by the black lines is present in the tissue. At $t=t_{n+1}$ the black generation has degraded partially, whereas a new (blue) generation is created. Finally, at $t=t_{n+2}$ the blue generation starts degrading, the black one vanishes almost completely, and the red one is just deposited

Directions of collagen fibres belonging to the new generation form a distribution, which depends on the local principal stretch directions of the tissue $v_{1}$ and $v_{2}$ (Fig. 2).

Each individual deposited collagen fibre is supposed to attach to the tissue with a constant prestretch $\lambda_{a}$, which is the collagen stretch at the homeostatic state. The unstretched length of collagen fibres is governed by remodeling history, and may, therefore, differ over the generations (Fig. 3).

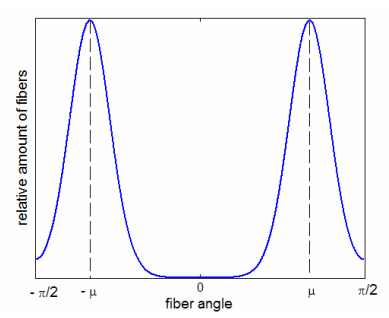

Fig. 2 Distribution of collagen fibre directions of collagen generation at the moment of its creation. The fibre directions are presented with respect to local principal stretch direction of largest stretch; $\mu$ is the main fibre angle

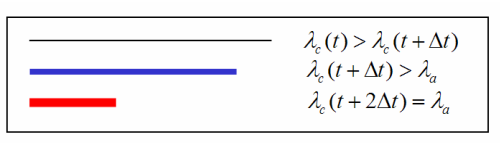

Fig.3 Stretch of collagen fibres, belonging to the black, the blue, and the red collagen generations, see Fig. 1

The rate of total mass of collagen is given by

$$
\dot{M}_{c}(t)=\dot{M}_{c}^{(h)}(t)+\dot{M}_{c}^{(e)}(t),
$$

where

$$
\dot{M}_{c}^{(e)}(t)=K_{g}\left(\bar{\lambda}_{c}-\lambda_{a}\right),
$$

$\dot{M}_{c}^{(h)}(t)$ the homeostatic production of collagen compensating for collagen degradation, $\dot{M}_{c}^{(e)}(t)$ the extra collagen production triggered by the violation of homeostatic stretch state, $\bar{\lambda}_{c}$ the collagen stretch averaged over generations and directions, and $K_{g}$ is the coefficient of growth.

Tissue growth. The extra mass $M_{c}^{(e)}(t)$ corresponds to a distribution of a relative volume change $J_{g}^{\text {des }}(t)$ throughout the tissue, that must be accommodated in a compatible way, maintaining tissue integrity. This is realized through a growth mechanics computation, using the following constitutive relation that drives the tissue to the desired volume change

$$
\boldsymbol{\sigma}^{\mathrm{virt}}=\kappa\left(J_{g}-J_{g}^{\mathrm{des}}\right) \boldsymbol{I}+\frac{c}{J_{g}^{\mathrm{des}}}\left(\boldsymbol{F}_{g} \boldsymbol{F}_{g}^{T}-J_{g}^{2 / 3} \boldsymbol{I}\right),
$$

with $\sigma^{\text {virt }}$ the virtual tissue stress during growth, $\kappa$ and $c$ the bulk modulus and the shear modulus of the matrix respectively, $J_{g}=\operatorname{det} \boldsymbol{F}_{g}$ the actual volume change realized. The deformation gradient $\boldsymbol{F}_{g}$ is determined on satisfying an equilibrium condition $\operatorname{div} \boldsymbol{\sigma}^{\text {virt }}=0$, and stress free boundary conditions in load free configuration using (1).

\section{Results}

The model was tested by determining a homeostatic state of cylindrical artery. At this state collagen stretch equals $\lambda_{a}$ at each fibre direction, yielding no extra collagen production, and, consequently, no growth. Distribution of fibre directions is the same for all generations, changing in radial direction only. The results shown in Fig. 4 suggest that collagen fibres at the outer surface are more axially oriented and less uniform than the fibres at the inner surface, which is in agreement with histology.
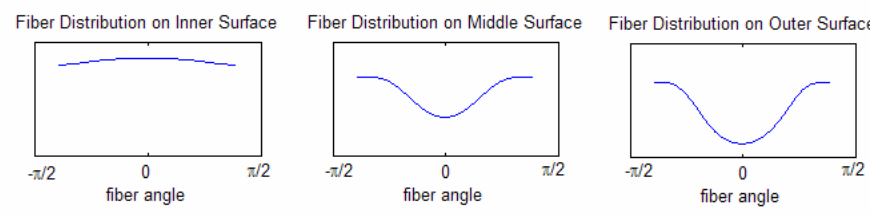

Fig. 4 Distribution of collagen fibre angles with respect to the circumferential direction, at different radial positions of cylindrical artery at homeostatic state

\section{Future work}

Presented model of arterial G\&R will be applied to cerebral arteries in order to predict aneurysm development. 